Gut, 1985, 26, 1312-1318

\title{
Histochemical demonstration of desialation and desulphation of normal and inflammatory bowel disease rectal mucus by faecal extracts
}

\author{
J M RHODES, R R BLACK, R GALLIMORE, AND A SAVAGE \\ From the Departments of Medicine, Queen Elizabeth Hospital and Selly Oak Hospital, Birmingham and \\ Department of Histopathology, Selly Oak Hospital, Birmingham
}

SUMMARY Experiments were carried out to assess the susceptibility of normal and inflammatory bowel disease rectal mucus to desulphation and desialation by faecal extracts and by bacterial sialidase. The effects were assessed histochemically using a combined high iron diamine (HID) and alcian blue (AB) stain for sulphomucins and sialomucins. Rectal mucus in biopsies from controls (irritable bowel syndrome) and patients with ulcerative colitis or Crohn's disease was resistant to desialation by Clostridium perfringens sialidase, but susceptible to desialation and desulphation by bacteria-free extracts of normal faeces. Periodic acid-Schiff (PAS) staining of adjacent sections similarly treated showed retention of neutral mucus. One faecal extract selectively desulphated all 42 biopsies, causing the goblet cells to change from HID positive to $\mathrm{AB}$ positive, suggesting that most, or all HID positive cells also contain sialomucins. This alters the interpretation of previous histochemical studies. Faecal extracts from patients with active ulcerative colitis $(n=6)$ had desialating and desulphating effects similar to faecal extracts from normal subjects $(n=6)$. Ulcerative colitis $(n=21)$, Crohn's disease $(n=18)$, and control (irritable bowel syndrome) $(n=17)$ rectal biopsies all showed similar susceptibility to desulphation by a pooled normal faecal extract, but rectal biopsies from patients with Crohn's disease proved more resistant to desialation than control or ulcerative colitis biopsies $(\mathrm{p}<0.02)$. These studies imply that colonic mucus undergoes continual desulphation and desialation in vivo as a result of faecal enzyme activity that is probably mainly of bacterial origin. Altered susceptibility of colonic mucus to this may be important in the pathogenesis of colonic disease.

Depletion of goblet cell mucus is a striking histological feature of active ulcerative colitis. ${ }^{12}$ Histochemical studies have shown that there is also a reduction of the ratio of sulphomucins to sialomucins in active disease. ${ }^{3}$ It has been shown that mucus, once released, is degraded in the colonic lumen by bacterial glycosidases. ${ }^{4} \mathrm{~A}$ hypothesis follows from this that ulcerative colitis could be caused by an inherited defect in colonic mucus that renders it unusually susceptible to enzymatic degradation by bacterial exoenzymes. In view of this it is interesting that Podolsky and Isselbacher have recently described selective reduction of a colonic mucin subclass in ulcerative colitis. ${ }^{5}$ To date, however, no studies have been published showing

Address for correspondence: Dr J M Rhodes, Department of Medicine, Walton Hospital, Rice Lane, Liverpool.

Received for publication 15 March 1985 any functional abnormality in ulcerative colitis mucus.

There is relatively little neutral mucus normally present in the colon, most of the mucus being sulphated or sialated. ${ }^{6}$ Sulphation and sialation may both be potentially important by increasing the resistance of mucus to bacterial degradation. Sulphate groups on subterminal sugars in the mucus glycoprotein increase their charge ${ }^{7}$ and probably alter the tertiary structure of the mucin as well as rendering the mucin sugars less susceptible to cleavage. ${ }^{8}$ Sialic acid if present is thought always to be present as a terminal sugar on the mucus glycoprotein side chain. ${ }^{9}$ As most bacterial glycosidases are probably exoglycosidases - that is, able only to cleave off terminal sugars, the sialic acid would have to be removed by sialidase (neuraminidase) first but histochemical studies have shown that 
colonic mucus sialic acid is usually markedly resistant to sialidase,${ }^{10}$ probably as a result of side groups substituted on the sialic acid causing steric hindrance to sialidase. ${ }^{1112}$ Abnormalities of sulphation or sialation, possibly including abnormalities in the sialic acids themselves, could therefore lead to altered susceptibility to bacterial degradation and hence be of considerable pathogenic importance in colonic disease.

Histochemical techniques are available which distinguish sulphomucins from sialomucins. ${ }^{6}{ }^{13}$ In the present study these techniques have been used to determine the susceptibility of normal and diseased rectal mucosae to desulphation and desialation by faecal enzymes.

\section{Methods}

\section{PATIENTS}

Rectal biopsies were obtained in all from 17 irritable bowel syndrome subjects (controls, aged 20-53 years, all histologically normal) and from 27 patients with ulcerative colitis (aged 18-63 years) and 24 with Crohn's disease (aged 17-65 years) all in clinical remission and diagnosed according to conventional histological and radiological criteria. All the ulcerative colitis patients had had previous active colitis extending at least to the splenic flexure. The ulcerative colitis and Crohn's disease biopsies were all histologically uninflamed or only mildly inflamed without evidence of mucus depletion. Twenty two of the Crohn's disease patients had radiological evidence of ileocolonic disease and the remaining two had ileal disease only. The biopsies were fixed in $10 \%$ formal saline and paraffin embedded.

Faecal samples were obtained from eight healthy controls (university students), six patients with active ulcerative colitis and six patients with active Crohn's disease, none of whom had received drug therapy during the previous month. The samples were frozen at $-20^{\circ} \mathrm{C}$ within four hours of voiding. Before the study the faecal samples were thawed, homogenised in acetate or Tris acetate buffer at varying $\mathrm{pH}$ (see below), centrifuged for 30 minutes at $15000 \mathrm{~g}$ and the supernatants then filtered through a series of filters culminating in a $0.22 \mu \mathrm{m}$ pore diameter filter to yield a bacteria free filtrate (confirmed on culture). These filtrates were then concentrated by ultrafiltration to produce a final filtrate that represented a five-fold dilution of the original faecal sample. Clostridium perfringens neuraminidase (sialidase) was obtained from Sigma (UK).

HISTOCHEMISTRY

Five micron thick sections were mounted on glass slides, deparaffinated in xylene and passed from absolute ethanol into Tris acetate buffer (see below). They were then incubated for 12 to 24 hours (see below) at $37^{\circ} \mathrm{C}$ in the faecal or bacterial extract under test. In each experiment an adjacent section from the same biopsy was incubated under the same conditions in buffer alone as control. After incubation sections were stained either with periodic acid-Schiff (PAS) or with a combined high iron diamine (HID) and alcian blue ( $\mathrm{pH} 2 \cdot 5)(\mathrm{AB})$ stain which stains sialomucins blue and sulphomucins black. ${ }^{13}$ The slides were then reviewed blindly and graded separately for HID and AB staining intensity on an arbitrary scale from $0-5$. Results were then expressed as change in grade of HID and $A B$ intensity after incubation in test substance compared with $\mathrm{HID}$ and $\mathrm{AB}$ intensity of the adjacent control section incubated in buffer alone.

\section{EXPERIMENTAL}

Four groups of experiments were carried out as follows: (i) Sections from six control, six ulcerative colitis, and six Crohn's disease rectal biopsies were incubated for 24 hours with Clostridium perfringens sialidase $0.04 \mathrm{IU} / \mathrm{ml}$ (equivalent to 186 'old' Behringwerke units $/ \mathrm{ml})^{12}$ in $0.1 \mathrm{M}$ acetate buffer $\mathrm{pH}$ 5.5 (with and without sodium deoxycholate 1 $\mathrm{mg} / \mathrm{ml}$ ). (ii) Further sections from the six control rectal biopsies used in (i) were incubated for 24 hours in faecal extracts from six normal subjects, six patients with active ulcerative colitis and six patients with Crohn's disease. The faecal extracts were prepared in $0.2 \mathrm{M}$ Tris acetate buffer $\mathrm{pH} 6 \cdot 5$. (iii) Further sections from the six control, six ulcerative colitis and six Crohn's disease rectal biopsies used in (i) were incubated for 24 hours with (a) an ulcerative colitis faecal extract which had been previously shown to have a marked selective desulphating effect; (b) a Crohn's disease faecal extract previously shown to have a marked desialating and desulphating effect; (c) the same faecal extracts as in (a) and (b) with sodium azide $200 \mathrm{mg} / \mathrm{l}$ or Thimerasyl $100 \mathrm{mg} / \mathrm{l}$ added; (d) a faecal extract prepared by pooling together six active ulcerative colitis extracts. All these extracts were prepared in $0.2 \mathrm{M}$ Tris acetate buffer $\mathrm{pH}$ 6.5. (iv) Sections from 17 control, 21 ulcerative colitis and 18 Crohn's disease rectal biopsies were incubated for 12 hours in a faecal extract prepared by pooling together eight normal faecal extracts (in $0.2 \mathrm{M}$ Tris acetate $\mathrm{pH} \mathrm{7.5)}$ ). This $\mathrm{pH}$ value was selected so as to approximate to the pH optimum of faecal sialidase (7.0) and sulphatase (8.5) as well as to physiological $\mathrm{pH}$.

FLUORIMETRIC FAECAL ENZYME ASSAYS

Aliquots of the faecal extracts used in experiments 
(ii), (iii) and (iv) were assayed fluorimetrically for sialidase and sulphatase using as substrates 4methylumbelliferyl sodium $\mathrm{N}$-acetyl neuraminate and 4-methylumbelliferyl sodium sulphate (Koch Light). Assays were carried out at $37^{\circ} \mathrm{C}$ over 15 minutes and stopped by the addition of $1.35 \mathrm{M}$ glycine buffer $\mathrm{pH} 10 \cdot 7$. Sialidase was assayed at $\mathrm{pH}$ 4.6 (the optimum $\mathrm{pH}$ for Clostridium perfringens neuraminidase in this assay) and sulphatase at $\mathrm{pH}$ 's 6.5 and $7 \cdot 5$.

\section{Results}

(i) The HID/AB staining of six control, six ulcerative colitis and six Crohn's disease rectal biopsies were all unaffected by incubation for 24 hours in Clostridium perfringens sialidase $0.04 \mathrm{IU} / \mathrm{ml}$ with and without sodium deoxycholate $1 \mathrm{mg} / \mathrm{ml}$. (ii) The $\mathrm{HID} / \mathrm{AB}$ staining of six normal rectal biopsies was, however, markedly affected by prior incubation in the faecal extracts. Most of the 18 faecal extracts tested had a marked desialating effect; the six ulcerative colitis faecal extracts causing less desialation (mean change in sialomucin grading $-1 \cdot 2 \pm 1 \cdot 6$ sd) than the six normal faecal extracts (mean change in sialomucin grading $-2.4 \pm 1.6 \mathrm{sd}$ ) or the six Crohn's disease faecal extracts (mean change in sialomucin grading $-3.3 \pm 1.0 \mathrm{sd}$ ) (Fig. 1). Considerable desulphation of rectal mucus also resulted from incubation in the faecal extracts: normal faecal extracts mean change in sulphomucin grading $-1 \cdot 5 \pm 1 \cdot 3$ ulcerative colitis faecal extracts mean change in sulphomucin grading $-1.1 \pm 1.5 \mathrm{sd}$, Crohn's disease faecal extracts mean change in sulphomucin grading $-2 \cdot 6 \pm 1 \cdot 5 \mathrm{sd}$ (Fig. 2). Periodic acid-Schiff staining of adjacent sections that had been incubated in the same faecal extracts showed preservation of neutral mucins in goblet cells and no evidence of architectural damage (Figs. 3-6). (iii) In

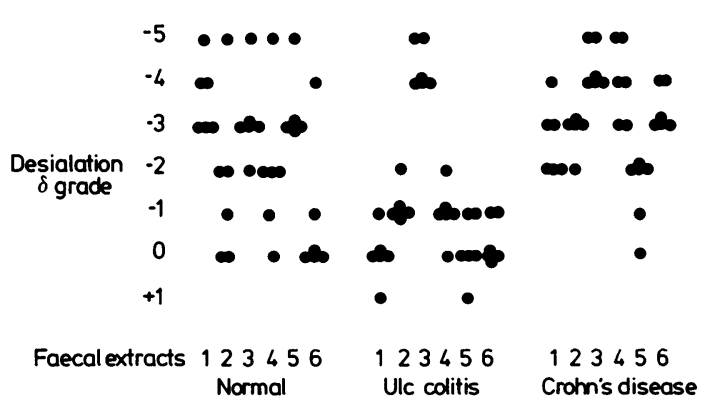

Fig. 1 Desialation of control (irritable bowel syndrome) rectal biopsies $(n=6)$ by normal, ulcerative colitis and Crohn's disease faecal extracts.

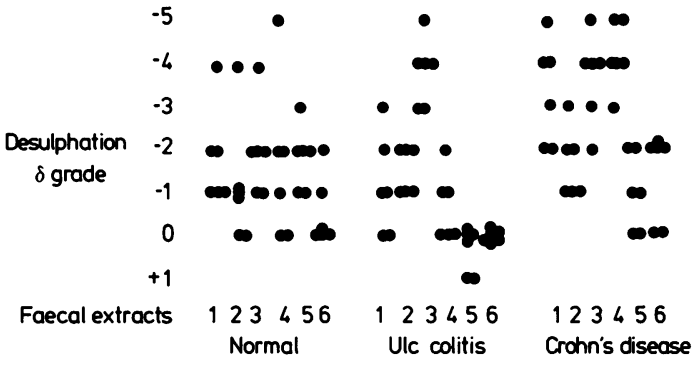

Fig. 2 Desulphation of control (irritable bowel syndrome) rectal biopsies $(n=6)$ by normal ulcerative colitis and Crohn's disease faecal extracts.

a preliminary experiment two faecal extracts designated ' $S$ ' and ' $U$ ' had particularly marked effects on $\mathrm{HID} / \mathrm{AB}$ staining. Incubation in faecal extract ' $\mathrm{S}$ ' (from a patient with active ulcerative colitis) was found reproducibly to desulphate all rectal biopsies tested from controls and patients with ulcerative colitis or Crohn's disease (42 biopsies in all in two separate experiments). After incubation in this faecal extract the goblet cells that were sulphomucin containing (HID positive) in buffer-incubated control sections were found to have been converted to sialomucin staining (AB positive) (Fig. 4). Incubation in faecal extract ' $U$ ' (from a patient with active Crohn's disease) resulted in total loss of all HID/AB staining in all 42 biopsies tested (including controls, ulcerative colitis and Crohn's disease) although PAS staining of adjacent sections similarly treated showed preservation of neutral mucins. The desialating and desulphating effects of faecal extracts ' $S$ ' and ' $U$ ' were completely inhibited by addition of Thimerasyl $100 \mathrm{mg} / \mathrm{ml}$ before incubation of the rectal biopsies while addition of sodium azide 200 $\mathrm{mg} / \mathrm{ml}$ had no effect. The normal, ulcerative colitis and Crohn's disease rectal biopsies showed similar susceptibilities to desialation and desulphation by a faecal extract prepared by pooling six extracts from patients with active ulcerative colitis (Fig. 7).

(iv) In this experiment the 17 control, 21 ulcerative colitis and 18 Crohn's disease rectal biopsies showed similar susceptibility to desulphation by a faecal extract pooled from eight normal faecal samples (Fig. 8). The Crohn's disease rectal biopsies unexpectedly proved more resistant to desialation than the control or ulcerative colitis biopsies ( $\mathrm{p}<0.02$ by Kruskall-Wallace ANOVAR by ranks) (Fig. 8).

In every biopsy the control section incubated in buffer showed a normal distribution of HID/AB staining with intense HID+ve sulphomucin staining in lower crypts and $\mathrm{AB}+\mathrm{ve}$ sialomucin staining in 

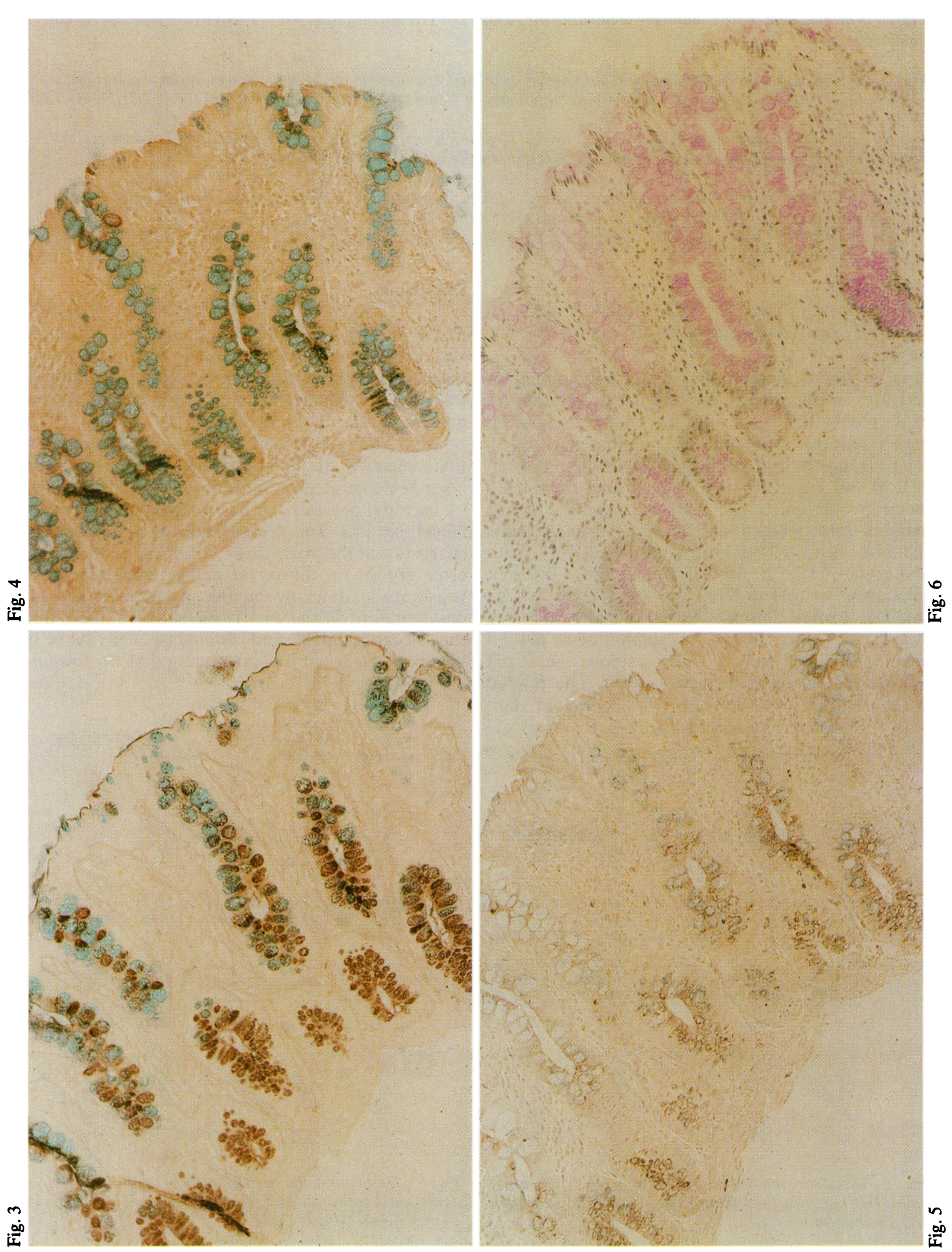

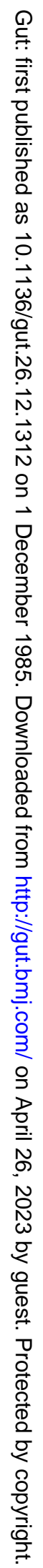


Fig. 3 Normal rectal biopsy following incubation for 24 hours in Tris acetate buffer pH 6.5 (High iron diamine/Alcian blue $\times 150)$.

Fig. 4 Section from same normal rectal biopsy as Fig. 1 following incubation for 24 hours in an ulcerative colitis faecal extract ('S') showing conversion of HID staining sulphomucins (black) to AB staining sialomucins (blue) $(H I D / A B \times 150)$.

Fig. 5 Section from same normal rectal biopsy as Fig. 1 following incubation for 24 hours in a Crohn's disease faecal extract showing loss of almost all sulphomucins $(H I D)$ and sialomucins $(A B)(H I D / A B \times 150)$.

Fig. 6 Section from same normal rectal biopsy as Fig. 3 following incubation in the same Crohn's disease faecal extract showing preservation of PAS staining neutral mucins $(P A S \times 150)$.

upper crypts.

\section{FLUORIMETRIC ASSAY OF FAECAL ENZYME ACTIVITY}

Fluorimetric estimation of sialidase and sulphatase activities in aliquots of the faecal extracts used in experiments (ii), (iii) and (iv) were as follows: experiment (ii), normal controls sialidase mean $0 \cdot 10$ $\mathrm{IU} / \mathrm{ml}$ (range $0.01-0.30$ ) sulphatase at $\mathrm{pH} 6.5$ mean $0.02 \mathrm{IU} / \mathrm{ml}$ (range $0-0.05$ ), sulphatase at $\mathrm{pH} 6.5$ mean $0.01 \mathrm{IU} / \mathrm{ml}$ (range $0-0.04$ ); ulcerative colitis extracts (also pooled as ' $\mathrm{d}$ ' in experiment (iii)) sialidase mean $0.17 \mathrm{IU} / \mathrm{ml}$ (range $0.03-0.45$ ), sulphatase at $\mathrm{pH} 7.5$ mean $0.12 \mathrm{IU} / \mathrm{ml}$ (range $0-0.51$ ), sulphatase at $\mathrm{pH} 6.5$ mean $0.02 \mathrm{IU} / \mathrm{ml}$ (range 0-0.09); Crohn's disease extracts: sialidase mean $0.29 \mathrm{IU} / \mathrm{ml}$ (range 0.09-0.59), sulphatase at $\mathrm{pH} 7.5$ mean $0.07 \mathrm{IU} / \mathrm{ml}$ (range $0-0.11$ ), sulphatase at $\mathrm{pH}$ 6.5 mean $0.01 \mathrm{IU} / \mathrm{ml}$ (range $0-0.03$ ). The pooled normal extract in experiment (iv) contained sialidase $0.13 \mathrm{IU} / \mathrm{ml}$ and sulphatase $0.16 \mathrm{IU} / \mathrm{ml}$ at $\mathrm{pH}$ $7 \cdot 5,0.01 \mathrm{IU} / \mathrm{ml}$ at $\mathrm{pH} 6.5$.

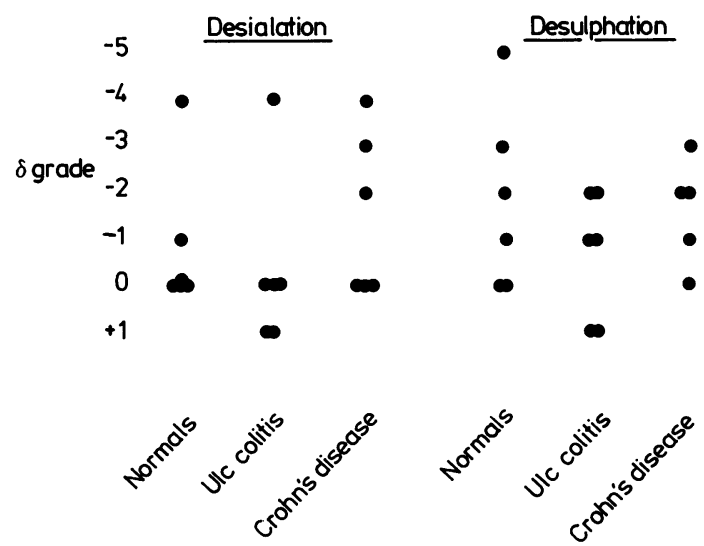

Fig. 7 Desialation and desulphation of control, ulcerative colitis (UC) and Crohn's disease rectal biopsies by a pooled UC faecal extract.

\section{Discussion}

These studies show that normal rectal mucus is susceptible to desialation and desulphation by bacteria free extracts of normal faeces. Inhibition of this effect by Thimerasyl suggests that it is enzyme mediated and the preservation of neutral (PAS positive HID/AB negative) rectal mucus suggests that selective desulphation and desialation have been demonstrated rather than non-specific damage by bacterial proteases or glycosidases present in the faecal extracts. The preservation of neutral mucus suggests that the presence of sialic acid and sulphate ester groups on the rectal mucus confers relative resistance to attack by the mucus degrading glycosidases present in faeces. ${ }^{4}$ It seems most likely that the faecal sialidase and sulphatase activity is of bacterial origin but it is interesting that Clostridium

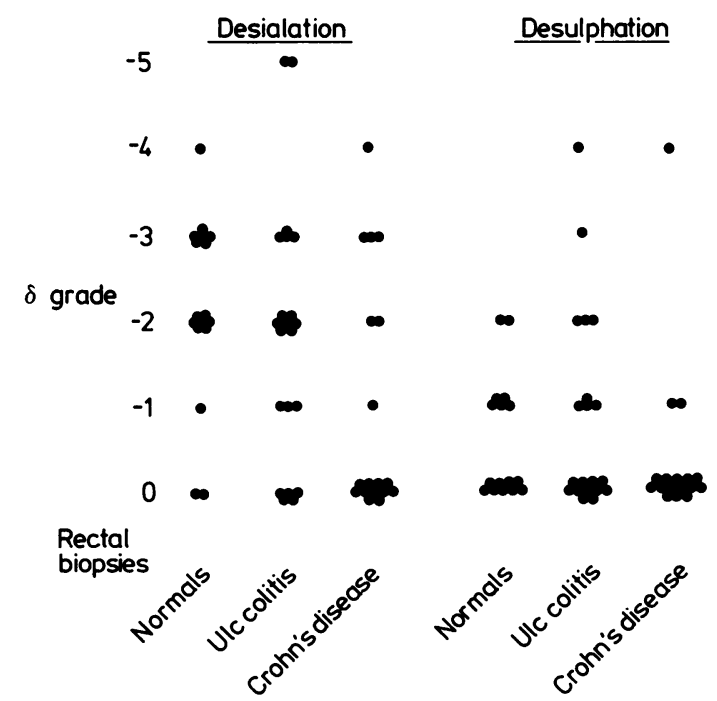

Fig. 8 Desialation and desulphation of control, ulcerative colitis and Crohn's disease rectal biopsies by a pooled normal faecal extract. 
perfringens sialidase has no effect on rectal sialomucins. Cholera sialidase has also been shown to have very little or no effect on colonic mucus unless the mucosa is previously treated with potassium hydroxide. $^{101214}$ It is well recognised, however, that sialidases produced by different organisms may have different substrate specificities. ${ }^{15}$

It is disappointing that ulcerative colitis rectal mucosa was found to be no more susceptible than normal rectal mucosa to either desialation or desulphation. It is still possible that it might prove more susceptible to a bacterial sulphatase or sialidase present in faeces at the onset of an attack of colitis but absent from the faecal extracts tested in this study. The relative resistance of Crohn's disease rectal mucus to desialation is interesting. It is known that in colonic Crohn's disease there is relative preservation of goblet cell mucus even in the presence of inflammation. ${ }^{2}$ It is possible that this may be because of increased resistance of Crohn's disease rectal mucus to bacterial degradation. This would at first sight seem to be an advantage and therefore unlikely to be relevant to the pathogenesis of Crohn's disease but increased resistance of the mucus to degration might be associated with some other mucus abnormality, possibly rheological, that is disadvantageous.

In this study extracts prepared from a faecal sample from one patient with active ulcerative colitis were found reproducibly to cause selective desulphation with little desialation of all biopsies tested. It then became clear that all the goblet cells which contained black (HID) staining sulphomucin after incubation in buffer also contained sialomucins as the same crypts could be identified in the adjacent sections treated with this faecal extract and then contained only strongly alcian blue positive (sialomucin containing) cells. This effect was seen in all 42 biopsies incubated in this extract. This suggests that goblet cells that seem with the HID/AB staining technique to contain only sulphomucin also contain sialomucins whose uptake of alcian blue is presumably masked by the intensity of the HID staining. It is possible that the same mucins are both sialated and sulphated or even that the sialic acid is itself sulphated. ${ }^{16}$ This finding affects the interpretation of previous histochemical studies of colonic mucus where the HID/AB stain has been used. In these studies sialomucins have been identified by deduction as those mucins which stain with $\mathrm{AB}$ but not HID because AB at pH 2.5 stains all acid mucins that is, both sulphomucins and sialomucins, while HID selectively stains sulphomucins. Increased $A B$ staining in HID/AB stained sections has then been taken to imply increased sialomucin content, as for example in a recent report of altered mucin staining in inflammatory bowel disease and colonic dysplasia. ${ }^{3}$ The present study shows, however, that sulphomucin containing goblet cells almost invariably contain sialomucin as well so the only firm conclusion that can be drawn from studies showing reduced HID and increased $A B$ staining is that there is a reduction in sulphomucin. Conclusions about the sialomucin content of mucosa that also contains sulphomucins will therefore have to be based on quantitative biochemical estimation ${ }^{17} 18$ rather than on histochemical staining patterns.

Although some faecal extracts were found to have a more potent desialating or desulphating effect than others, there was no overall tendency for faecal extracts from patients with active ulcerative colitis or Crohn's disease to have any greater effect on rectal mucus than extracts of faeces from healthy controls. This is in keeping with the results of biochemical estimations of faecal enzyme activity. ${ }^{19}{ }^{20}$ In the present study, however, there was a very poor correlation between sulphatase and sialidase activity assayed fluorimetrically and the effects on mucus demonstrable histochemically. This was most marked with faecal sulphatase which has a high $\mathrm{pH}$ optimum $(\mathrm{pH} 8 \cdot 5)^{21}$ when assayed fluorimetrically with little or no activity at $\mathrm{pH} 6.5$ yet histochemically demonstrable desulphation was as marked at $\mathrm{pH} 6.5$ as at $\mathrm{pH} \mathrm{7.5}$. This lack of correlation is likely to be caused by differences in substrate specificity of the faecal sialidases and sulphatases.

It seems likely that colonic mucus is continuously undergoing desialation and desulphation by bacterial enzymes as an initial step in its degradation. While this study has failed to show any differential susceptibility of ulcerative colitis rectal mucus to desialation or desulphation the increased resistance to desialation of Crohn's disease rectal mucus may be of pathogenic importance and might explain why mucus tends to be retained in colonic Crohn's disease even in the presence of inflammation.

We would like to thank Dr $\mathrm{H}$ Thomson for the loan of histological material. This work was supported by a grant from the Birmingham Central District Endowment Fund.

\section{References}

1 Hellstrom HR, Fisher ER. Estimation of mucosal mucin as an aid in the differentiation of Crohn's disease of the colon and chronic ulcerative colitis. Am J Clin Pathol 1967; 48: 259-68.

2 Filipe MI, Dawson I. The diagnostic value of mucosubstances in rectal biopsies from patients with ulcera- 
tive colitis and Crohn's disease. Gut 1970; 11: 229-34.

3 Ehsanullah M, Filipe MI, Gazzard B. Mucin secretion in inflammatory bowel disease: correlation with disease activity and dysplasia. Gut 1982; 23: 485-9.

4 Hoskins LE, Boulding ET. Mucin degradation in human colon ecosystems. Evidence for the existence and role of bacterial sub populations producing glycosidases as extracellular enzymes. J Clin Invest 1981; 67: 163-72.

5 Podolsky DK, Isselbacher KJ. Composition of human colonic mucin. Selective alteration in inflammatory bowel disease. J Clin Invest 1983; 72: 142-53.

6 Filipe MI. Mucins in the human gastrointestinal epithelium: a review. Invest Cell Pathol 1979; 2: 195-216.

7 Dodgson KS, White GF, Fitzgerald JW, eds. Sulfatases of microbial origin. Harrow, Mx: CRC, 1982: 1-7.

8 Mian N, Andersen CE, Kent PW. Neuraminidase inhibitions by chemically sulphated glycopeptides. Biochem J 1979; 181: 377-85.

9 Schrager J, Oates MDG. Relation of human gastrointestinal mucus to disease states. Br Med Bull 1978; 34: 79-82.

10 Makela V, Korhonen LK, Lilius G. Carbohydrate-rich compounds in the colonic mucosa of man. 1. Histochemical characteristics of normal and adenomatous colonic mucosa. Cancer 1971; 27: 120-7.

11 Reid PE, Culling CFA, Dunn WL. Saponificationinduced increase in the periodic acid-Schiff reaction in the gastrointestinal tract. Mechanism and distribution of the reactive substance. J Histochem Cytochem 1973; 21: 473-82.

12 Culling CFA, Reid PE, Clay MG, Dunn WL. The histochemical demonstration of $\mathrm{O}$-acylated sialic acid in gastrointestinal mucins: their associations with the potassium hydroxide-periodic acid-Schiff effect. $J$ Histochem Cytochem 1974; 22: 826-31.

13 Spicer SS. Diamine methods for differentiating mucosubstances histochemically. J Histochem Cytochem 1965; 13: 211-34.

14 Filipe MI. Value of histochemical reactions for mucosubstances in the diagnosis of certain pathological conditions of the colon and rectum. Gut 1969; 10: 577-86.

15 Schauer R. Glycosidases with special reference to the pathophysiological role of sialidase. In: Popper H, ed. Structural carbohydrates in the liver. Lancaster: MTP Press, 1983: 83-97.

16 Mian N, Andersen CE, Kent PW. Effect of the $\mathrm{O}$-sulphate groups in lactose and $\mathrm{N}$-acetylneuraminyllactose on their enzymic hydrolysis. Biochem J 1979; 181: 387-99.

17 Barker SA, Stacey M, Tipper DJ. Some observations on certain mucoproteins containing sialic acid. Nature 1959; 184: 68-9.

18 Filipe MI, Cooke KB. Changes in composition of mucin in the mucosa adjacent to carcinoma of the colon as compared with the normal: a biochemical investigation. J Clin Pathol 1974; 27: 315-8.

19 Rhodes JM, Gallimore R, Elias E, Allan R, Kennedy JF. Faecal mucus degrading glycosidases in ulcerative colitis and Crohn's disease. Gut 1985; 26. 761-5.

20 Rhodes JM, Gallimore R, Elias E, Kennedy JF. Faecal sulphatase activity in health and inflammatory bowel disease. Gut 1985; 26: 466-9. 